\title{
Inheritance of Resistance to the Peanut Root-knot Nematode in Capsicum chinense
}

\author{
Richard L. Fery ${ }^{1}$ and Judy A. Thies ${ }^{2}$ \\ U.S. Department of Agriculture, Agricultural Research Service, U.S. Vegetable Laboratory, 2875 \\ Savannah Highway, Charleston, SC 29414-5334
}

AdDitional INDEX words. pepper, Meloidogyne arenaria, Capsicum annuum, soilborne pathogen, disease resistance, vegetable breeding

\begin{abstract}
Greenhouse experiments determined the inheritance of resistance to the peanut root-knot nematode [Meloidogyne arenaria (Neal) Chitwood race 1] in Capsicum chinense Jacq. germplasm lines PA-353 and PA-426. Evaluation of parental, $F_{1}, F_{2}$, and backcross populations of the crosses PA-353 x PA-350 and PA-426 x PA-350 (PA-350 is a susceptible cultigen) indicated that resistance in both $C$. chinense germplasm lines was conditioned by a single dominant gene. Evaluation of the $F_{1} \times$ resistant parent backcross populations in the cytoplasm of their respective resistant and susceptible parents indicated that the cytoplasm of the resistant parent is not needed for full expression of resistance. Allelism tests indicated that the dominant resistance gene in both PA-353 and PA-426 is allelic to a resistance gene in $C$. annuum L. 'Carolina Cayenne'. However, these allelism tests did not demonstrate conclusively that the M. arenaria race 1 resistance gene in $C$. chinense is the $N$ gene that conditions resistance to the southern root-knot nematode [Meloidogyne incognita (Kofoid \& White) Chitwood] in $C$. annuum. The ease and reliability of evaluating plants for resistance to rootknot nematodes and the availability of simply inherited sources of resistance makes breeding for peanut root-knot nematode resistance a viable objective in $C$. chinense breeding programs.
\end{abstract}

Although cultivars belonging to the species Capsicum annuum account for most of the peppers grown in the United States, cultivars belonging to the species $C$. chinense are becoming increasing popular. Two cultivar classes of $C$. chinense, Scotch Bonnet and Habanero, are now common in the United States. Capsicum chinense cultivars, like $C$. annuum cultivars, can be severely damaged by several species of the root-knot nematode (Meloidogyne Goeldi sp.). Recent research by Fery and Thies (1997) demonstrated that all $C$. chinense cultivars available to U.S. growers are susceptible to the southern root-knot nematode (Meloidogyne incognita). However, they identified several cultigens from heirloom collections that are resistant to $M$. incognita, and subsequently released the highly resistant Scotch Bonnettype germplasm lines PA-353, PA-398, and PA-426 (Fery and Thies, 1997, 1998a). Fery and Thies (1998b) also studied inheritance of southern root-knot nematode resistance in Scotch Bonnet-type $C$. chinense germplasm and determined that the resistance is conditioned by a single dominant gene.

Preliminary research by the authors (unpublished data) with the two known races of the peanut root-knot nematode $(M$. arenaria) indicates that only race 1 is highly pathogenic on $C$. chinense. Our research also indicated that the southern root-knot nematode resistant germplasm lines PA-353, PA-398, and PA426 are also highly resistant to $M$. arenaria race 1 . Meloidogyne arenaria is one of the four Meloidogyne species that has numerous crop plants as hosts, and it has a geographic distribution in the southern United States that is similar to that of M. incognita (Sasser and Carter, 1982). Research results in several published

\footnotetext{
Received for publication 7 Sept. 1999. Accepted for publication 20 June 2000 This work was supported, in part, by the Integrated Pest Management Collaborative Support Program (IPM CRSP), U.S. Agency for International Development (USAID), under Grant Numbers LAG-4196-G-00-3053-00 and LAG-G-00-9300053-00. Technical assistance of F.P. Maguire, E.L. Corley, and S.W. Miller is gratefully acknowledged. The cost of publishing this paper was defrayed in part by the payment of page charges. Under postal regulations, this paper therefore must be hereby marked advertisement solely to indicate this fact.

${ }^{1}$ Research geneticist.

${ }^{2}$ Research plant pathologist.
}

reports suggest that the single dominant gene in $C$. chinense identified by Fery and Thies (1998b) to condition resistance to $M$. incognita might not be responsible for conditioning the resistance to M. arenaria race 1. Di Vito et al. (1985) showed that the $C$. chinense 'Surrinam 8' is resistant to M. incognita and M. javanica (Treub) Chitwood (the javanese root-knot nematode), but not to M. arenaria. Later, Di Vito et al. (1993) and Di Vito and Saccardo (1996) demonstrated that resistances in C. chinense line 56-547/ 7 to $M$. incognita and $M$. javancia are conditioned by single dominant genes, but that resistance in the line to M. arenaria is conditioned by two duplicate dominant genes.

The root-knot nematode resistant $C$. chinense germplasm lines released by Fery and Thies (1998a) hold promise for pepper breeding programs to develop $C$. chinense cultivars with broad resistance to root-knot nematodes. However, the breeding value of these nematode resistant lines would be greatly enhanced if the modes of inheritance to all pertinent Meloidogyne species were understood. These needs prompted us to determine the inheritance of resistance to $M$. arenaria race 1 in the $C$. chinense germplasm, and to compare the genetic nature of the resistance exhibited by this germplasm to that exhibited by the $C$. аппиит 'Carolina Cayenne'.

\section{Materials and Methods}

The data reported are from a series of greenhouse experiments conducted at the U. S. Vegetable Laboratory, Charleston, S.C. Seeds of all parental, $F_{1}, F_{2}$, and backcross populations were produced in a greenhouse using standard crossing and selfing procedures. The tests were conducted in $4.1 \times 1.7 \times 0.2-\mathrm{m}$ benches containing a steam-pasteurized medium of 6 soil $: 3$ sand :1 peat (by volume). A slow-release, complete analysis fertilizer was incorporated into the medium, and the reaction was adjusted to $\mathrm{pH}$ 6.0. Seeds were germinated in flats containing a sterilized artificial growth medium, and seedlings were transplanted into the benches after true leaves had expanded. After the plants were established and growing, $5 \mathrm{~mL}$ tap water containing $\approx 3,000 \mathrm{M}$. arenaria race 1 eggs were pipetted around the base of each plant. 
Table 1. Gall indices, egg-mass indices, and number of eggs per gram fresh root tissue for parental and $\mathrm{F}_{1}$ populations of the crosses PA-353 x PA- 350 (Expt. 1A) and PA-426 x PA-350 (Expt. 1B) inoculated with the peanut root-knot nematode (Meloidogyne arenaria race 1).

\begin{tabular}{lccr}
\hline Population & $\begin{array}{c}\text { Gall } \\
\text { index }^{\mathrm{z}}\end{array}$ & $\begin{array}{c}\text { Egg-mass } \\
\text { index }^{\mathrm{y}}\end{array}$ & $\begin{array}{r}\text { No. eggs/ } \\
\text { g fresh } \\
\text { root tissue }\end{array}$ \\
\hline Expt. 1A & $1.00 \mathrm{~b}^{\mathrm{x}}$ & $1.00 \mathrm{~b}$ & $242 \mathrm{~b}$ \\
PA-353 $\left(\mathrm{P}_{1}\right)$ & $4.50 \mathrm{a}$ & $4.12 \mathrm{a}$ & $107,506 \mathrm{a}$ \\
PA-350 $\left(\mathrm{P}_{2}\right)$ & $1.00 \mathrm{~b}$ & $1.00 \mathrm{~b}$ & $391 \mathrm{~b}$ \\
$\mathrm{~F}_{1}\left(\mathrm{P}_{1} \times \mathrm{P}_{2}\right)$ & & & \\
Expt. 1B & $1.00 \mathrm{~b}$ & $1.00 \mathrm{~b}$ & $415 \mathrm{~b}$ \\
PA-426 $\left(\mathrm{P}_{3}\right)$ & $4.66 \mathrm{a}$ & $4.70 \mathrm{a}$ & $56,837 \mathrm{a}$ \\
PA-350 $\left(\mathrm{P}_{2}\right)$ & $1.12 \mathrm{~b}$ & $1.12 \mathrm{~b}$ & $896 \mathrm{~b}$ \\
$\mathrm{~F}_{1}\left(\mathrm{P}_{3} \times \mathrm{P}_{2}\right)$ & &
\end{tabular}

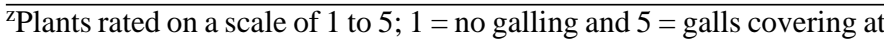
least $81 \%$ of root system.

yPlants rated on a scale of 1 to $5 ; 1=$ no egg masses and $5=$ egg masses covering at least $81 \%$ of root system.

'Mean separation within columns for an experiment by Duncan's multiple range test, $P \leq 0.01$.

Meloidogyne arenaria race 1 (obtained from S. L. Lewis, Clemson Univ., Clemson, S.C.) was maintained as an isolated culture on 'Rutgers' tomato (Lycopersicon esculentum Mill.) in the greenhouse. The inoculum used for all tests was extracted from $M$. arenaria-infected tomato roots using $0.5 \% \mathrm{NaOCl}$ (Hussey and Barker, 1973).

The planting arrangement was a $10 \times 12-\mathrm{cm}$ rectangular pattern (spacing between plants within rows: $10 \mathrm{~cm}$; spacing between rows: $12 \mathrm{~cm}$ ). To minimize the effect of moisture and temperature stress, the outer two rows of plants on the perimeter of each bench were utilized as buffers. Greenhouse air temperatures were maintained between 24 and $32^{\circ} \mathrm{C}$. All plants were evaluated 13 to 14 weeks after inoculation. Each plant received two subjective scores, one for the prevalence of root galling and another for the prevalence of egg masses. The following scale was used to score severity of galling: $1=$ no galls; $2=$ light galling, $1 \%$ to $25 \%$ of root system galled; $3=$ moderate galling, $26 \%$ to $50 \%$ of root system galled; $4=$ heavy galling, $51 \%$ to $80 \%$ of root system of root system galled; and $5=$ severe galling, $81 \%$ to $100 \%$ of root system galled. The number of egg masses per root system were scored as follows: $1=$ no egg masses evident; 2 = scattered egg masses covering $1 \%$ to $25 \%$ of the root system; $3=$ moderate number of egg masses covering $26 \%$ to $50 \%$ of the root system; $4=$ numerous egg masses covering $51 \%$ to $80 \%$ of the root system; and $5=$ extremely large numbers of egg masses covering $81 \%$ to $100 \%$ of the root system. All plants with gall severity scores of 1 or 2 were classified as resistant; plants scored 3 to 5 were classified as susceptible. Gall index, egg-mass index, and egg count data were analyzed using analysis of variance procedures, and means were separated using Duncan's multiple range test at $P \leq 0.01$. Chi-square tests for goodness-of-fit were used in testing genetic hypotheses.

INHERITANCE OF RESISTANCE (EXPTS. 1A AND B). Plants of the parental, $\mathrm{F}_{1}, \mathrm{~F}_{2}$, and backcross populations of the crosses PA-353 $\mathrm{X}$ PA-350 (Expt. 1A) and PA-426xPA-350 (Expt. 1B) were tested for resistance to $M$. arenaria race 1 . PA-353 and PA-426 are Scotch Bonnet-type germplasm lines that are highly resistant to $M$. arenaria race 1 (J.A. Thies and R.L. Fery, unpublished data). PA-350 is a Habanero-type germplasm line that is highly susceptible to $M$. arenaria race 1 (J.A. Thies and R.L. Fery, unpublished data). The experimental design of each experiment was a randomized com- plete block with four replications. Each plot contained five plants. Each replicate contained two plots of each resistant parent, two plots of each susceptible parent, two plots of the $F_{1}$ population (resistant parent $X$ susceptible parent), eight plots of the $F_{2}$ population, eight plots of the $F_{1} \times$ resistant parent backcross population, and eight plots of the $F_{1} \times$ susceptible parent backcross population. In 1998, the seeds for Expt. 1A were sown 14 Jan., the seedlings were trans-
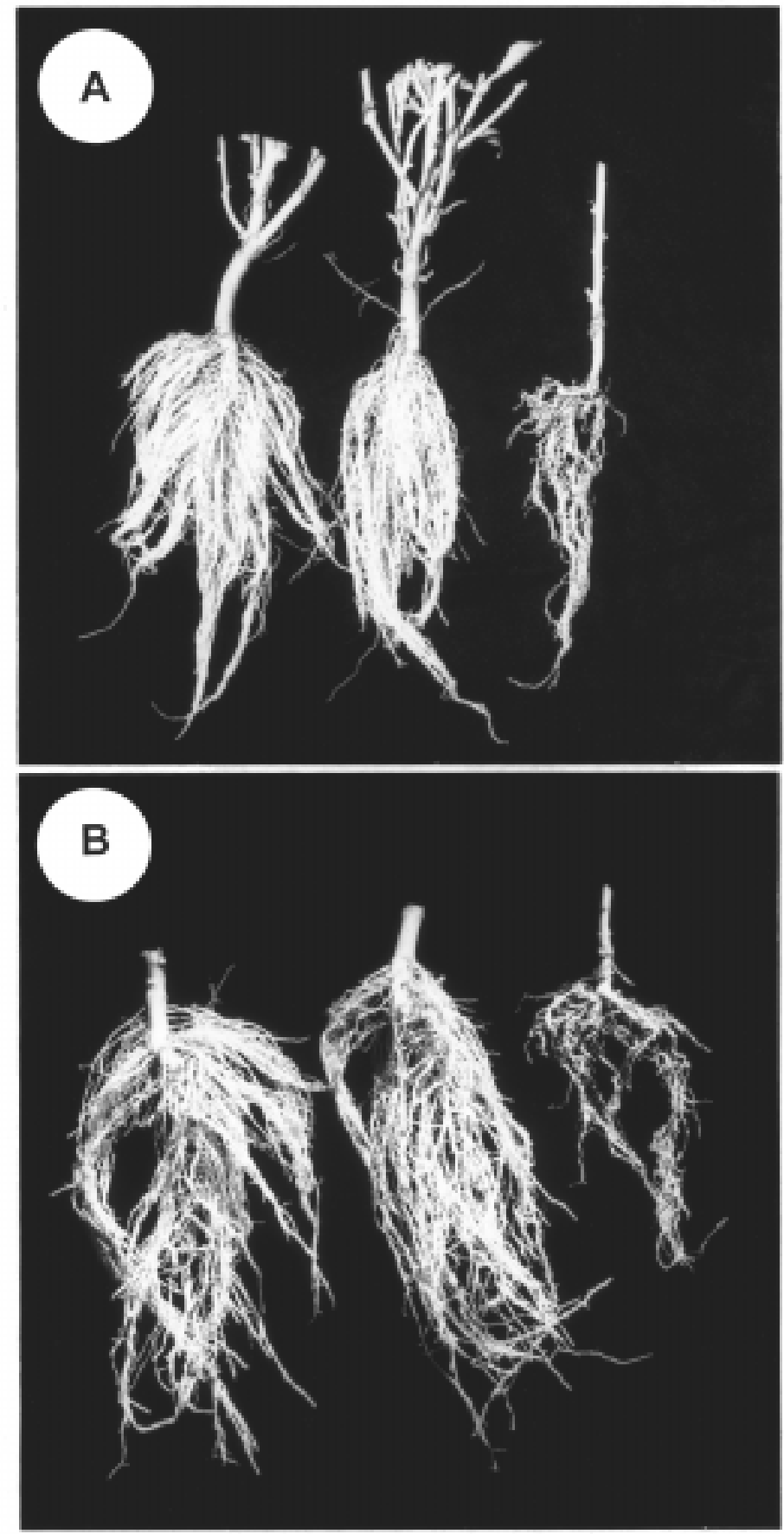

Fig.1. Examples of effects of the peanut root-knot nematode (Meloidogyne arenaria race 1) on the parental and $\mathrm{F}_{1}$ hybrid plants from $(\mathbf{A})$ Expt. $1 \mathrm{~A}$ and $(\mathbf{B})$ Expt. 1B. (A) Root systems of the resistant germplasm line PA-353 (left), the resistant $\mathrm{F}_{1}$ of PA-353 $\times$ PA- 350 (center), and the susceptible germplasm line PA-350 (right). (B) Root systems of the resistant germplasm line PA-426 (left), the resistant $\mathrm{F}_{1}$ of PA-426 $\times$ PA- 350 (center), and the susceptible germplasm line PA-350 (right). Note the lack of galls on the healthy root systems of the resistant parents and $F_{1}$ hybrids and the presence of numerous galls and extensive stunting of the susceptible PA-350 root systems. 
Table 2. Segregation for resistance to the peanut root-knot nematode (Meloidogyne arenaria race 1) in parental, $\mathrm{F}_{1}, \mathrm{~F}_{2}$, and backcross populations of the crosses PA-353 x PA-350 (Expt. 1A) and PA-426 x PA-350 (Expt. 1B).

\begin{tabular}{|c|c|c|c|c|c|}
\hline \multirow[b]{2}{*}{ Population } & \multicolumn{2}{|c|}{$\begin{array}{l}\text { No. plants } \\
\text { in classes }\end{array}$} & \multirow{2}{*}{$\begin{array}{c}\text { Expected } \\
\text { ratios } \\
(\mathrm{R}: \mathrm{S})^{\mathrm{z}}\end{array}$} & \multirow{2}{*}{$\begin{array}{c}\text { Chi } \\
\text { square }\end{array}$} & \multirow[b]{2}{*}{$P$} \\
\hline & Resistant & Susceptible & & & \\
\hline \multicolumn{6}{|l|}{ Expt. 1A } \\
\hline PA-353 $\left(\mathrm{P}_{1}\right)$ & 28 & & All R & --- & --- \\
\hline PA-350 $\left(\mathrm{P}_{2}\right)$ & & 27 & All S & --- & --- \\
\hline $\mathrm{F}_{1}\left(\mathrm{P}_{1} \times \mathrm{P}_{2}\right)$ & 20 & & All R & --- & --- \\
\hline $\mathrm{F}_{2}\left(\mathrm{P}_{1} \times \mathrm{P}_{2}\right)$ & 96 & 44 & $3: 1$ & 3.08 & 0.08 \\
\hline $\mathrm{F}_{1} \times \mathrm{PA}-353$ & 149 & & All R & --- & --- \\
\hline$F_{1} \times P A-350$ & 77 & 57 & $1: 1$ & 2.980 .08 & \\
\hline \multicolumn{6}{|l|}{ Expt. 1B } \\
\hline PA-426 $\left(\mathrm{P}_{3}\right)$ & 40 & & All R & --- & --- \\
\hline PA-350 $\left(\mathrm{P}_{2}\right)$ & & 40 & All S & --- & --- \\
\hline $\mathrm{F}_{1}\left(\mathrm{P}_{3} \times \mathrm{P}_{2}\right)$ & 11 & & All R & --- & --- \\
\hline $\mathrm{F}_{2}\left(\mathrm{P}_{3} \times \mathrm{P}_{2}\right)$ & 117 & 41 & $3: 1$ & 0.08 & 0.78 \\
\hline $\mathrm{F}_{1} \times \mathrm{PA}-426$ & 159 & & All R & --- & --- \\
\hline$F_{1} \times P A-350$ & 78 & 78 & $1: 1$ & 0.00 & 1.00 \\
\hline
\end{tabular}

${ }^{\mathrm{z}} \mathrm{R}=$ resistant (gall index $\leq 2$ ), $\mathrm{S}=$ susceptible (gall index $\geq 3$ ).

planted 3 Feb., established plants were inoculated 3 Mar., and the roots of each plant were evaluated 10 June. In 1999, the seeds for Expt. 1B were planted 15 Jan., the seedlings were transplanted 2 Feb., established plants were inoculated 23 Feb., and the roots of each plant were evaluated 25 May. For both experiments, the $1.05 \%$ $\mathrm{NaOCl}$ procedure was used to extract $M$. arenaria race 1 eggs from bulked, fibrous root samples of the parental and $F_{1}$ plots (Hussey and Barker, 1973).

Allelism STUdies (EXPTS. 2A AND B). Plants of the parental and $\mathrm{F}_{2}$ populations of the crosses PA-353 X 'Carolina Cayenne' (Expt. 2A) and PA-426 x 'Carolina Cayenne' (Expt. 2B) were tested for resistance to $M$. arenaria race 1 . 'Carolina Cayenne' is a $C$. annuum cultivar that is highly resistant to several root-knot nematode species, including $M$. arenaria, $M$. incognita, and $M$. javanica (Fery et al., 1986; Noe, 1992; Thies et al., 1997; Thies and Fery, 2000). The resistance in 'Carolina Cayenne' to $M$. incognita was derived by pure-line selection from 'Carolina Hot' (Fery et al., 1986); resistance in 'Carolina Hot' to M. incognita is conditioned by two genes, one dominant and one recessive (Fery and Dukes, 1996). The experimental design for both Expt. 2A and $\mathrm{B}$ was a randomized complete block with four replications. Each plot contained five plants. Each replicate contained two plots of each parental population and eight plots of the $\mathrm{F}_{2}$ population. Additionally, each replicate in Expt. 2A contained two control plots of the susceptible, bell-type C. annuum 'California Wonder' and each replicate in Expt. $2 \mathrm{~B}$ contained two control plots of the susceptible, Habanero-type $C$. chinense cultigen PA-350. In 1998, the seeds for Expt. 2A were sown 14 Jan., the seedlings were transplanted 3 Feb., established plants were inoculated 3 Mar., and the roots of each plant were evaluated 10 June. In 1999, the seeds for Expt. 2B were sown 15 Jan., the seedlings were transplanted 2 Feb., established plants were inoculated 23 Feb., and the roots of each plant were evaluated 25 May.

\section{Results and Discussion}

All of the parental lines reacted as expected. All of the plants of the susceptible parents exhibited strong susceptible reactions, and all of the plants of the resistant parents exhibited highly resistant reactions.
INHERITANCE OF RESISTAMCE (EXPTS. 1A AND B). EXamination of the gall indices, egg-mass indices, and the numbers of eggs per gram of fresh root tissue for the $F_{1}$ populations indicated that resistance to $M$. arenaria race 1 in PA-353 and PA-426 is inherited in a completely dominant manner (Table 1). In all cases, the resistance exhibited by the $F_{1}$ population was equal to that exhibited by the resistant parent (Fig. 1). The frequency of phenotypes in the progeny populations of Expt. 1A and Expt. 1B indicated that the $M$. arenaria race 1 resistance is conditioned by a single dominant gene in both PA-353 and PA-426 (Table 2). All $F_{1}$ plants were resistant and all of the $F_{1} x$ resistant parent backcross plants were of the expected resistant phenotype. The $\mathrm{F}_{2}$ populations segregated 3 resistant : 1 susceptible, and the $F_{1} x$ susceptible parent backcross populations segregated 1 resistant : 1 susceptible.

Although seed shortages prohibited evaluation of reciprocal $\mathrm{F}_{1}$ populations in Expts. $1 \mathrm{~A}$ and $\mathrm{B}$, supplemental studies were conducted concurrent with Expt. $1 \mathrm{~B}$ to evaluate both of the $\mathrm{F}_{1} \mathrm{X}$ resistant parent backcross populations in the cytoplasms of their respective resistant and susceptible parents (data not presented). All of these backcross populations segregated highly resistant plants, indicating that neither the PA-353 or PA-426 cytoplasms are needed for full expression of resistance.

Allelism STUdies (EXPTS. 2A AND B). All of the plants in the parental and $\mathrm{F}_{2}$ populations of the PA-353 $\mathrm{x}$ 'Carolina Cayenne' and PA-426 x 'Carolina Cayenne' crosses were resistant to $M$. arenaria race 1 (Table 3 ). Although all of the plants in the susceptible PA-350 control population in Expt. 2B were susceptible, the 'California Wonder' control population in Expt. 2A was, unexpectedly, heterogeneous for reaction to $M$. arenaria race 1. Based on our extensive use of 'California Wonder' as a susceptible control in numerous $M$. incognita studies in recent years, it is unlikely that the resistance observed in this 'California Wonder' population to $M$. arenaria race 1 is due to the $N$ gene reported to condition resistance to $M$. incognita in $C$. annuum (Fery and Dukes., 1996; Fery et al., 1998).

Lack of segregation in the $\mathrm{F}_{2}$ populations indicates that the dominant gene conditioning $M$. arenaria race 1 resistance in $C$. chinense germplasm lines PA-353 and PA-426 is allelic to a gene in C. annuum 'Carolina Cayenne'. It is tempting to conclude that 
Table 3. Segregation for reaction to the peanut root-knot nematode (Meloidogyne arenaria race 1) in parental and $\mathrm{F}_{2}$ populations of the interspecific crosses Capsicum chinense germplasm line PA-353 x C. annuum 'Carolina Cayenne' (Expt. 2A) and C. chinense germplasm line PA-426 x C. annuum cv. Carolina Cayenne (Expt. 2B).

\begin{tabular}{|c|c|c|c|c|c|}
\hline \multirow[b]{2}{*}{ Population } & \multicolumn{5}{|c|}{ No. plants in each gall-index class ${ }^{z}$} \\
\hline & 1 & 2 & 3 & 4 & 5 \\
\hline \multicolumn{6}{|l|}{ Expt. 2A } \\
\hline PA-353 $\left(\mathrm{P}_{1}\right)$ & 35 & & & & \\
\hline Carolina Cayenne $\left(\mathrm{P}_{4}\right)$ & 33 & & & & \\
\hline $\mathrm{F}_{2}\left(\mathrm{P}_{1} \times \mathrm{P}_{4}\right)$ & 156 & 1 & & & \\
\hline California Wonder ${ }^{\mathrm{y}}$ & 24 & & 10 & 4 & \\
\hline \multicolumn{6}{|l|}{ Expt. 2B } \\
\hline PA-426 $\left(\mathrm{P}_{3}\right)$ & 59 & & & & \\
\hline Carolina Cayenne ${ }^{\mathrm{x}}\left(\mathrm{P}_{4}\right)$ & 58 & & & & \\
\hline $\mathrm{F}_{2}\left(\mathrm{P}_{3} \times \mathrm{P}_{4}\right)$ & 199 & & & & \\
\hline PA-350w & & & 4 & 30 & 26 \\
\hline
\end{tabular}

index: resistant $\leq 2$, susceptible $\geq 3$

ySusceptible $C$. annuum control.

${ }^{\mathrm{x}}$ This population contained a single, susceptible plant. Plant was assumed to be the result of a seed mixture or planting error and was discarded.

${ }^{w}$ Susceptible C. chinense control.

the single dominant gene in the $C$. chinense germplasm lines conditioning the $M$. arenaria race 1 resistance is the same gene $(N)$ that Fery and Dukes (1996) and Fery and Thies (1998b) concluded was likely responsible for the bulk of the $M$. incognita resistance in the $C$. аnnuum and $C$. chinense germplasm they studied. However, another gene common to both $C$. аnnиит and $C$. chinense might be responsible for the $M$. arenaria race 1 resistance exhibited by the $C$. chinense germplasm lines evaluated in this study. Not only did we observe $M$. arenaria race 1 resistant plants in the 'California Wonder' population (presumed $n / n$ genotype) used as a control in Expt. $2 \mathrm{~A}$, but the work by Di Vito and his colleagues discussed above (Di Vito et al., 1985, 1993; Di Vito and Saccardo, 1996) provides examples of a $M$. incognita resistant $C$. chinense cultivar that is susceptible to $M$. arenaria and a $C$. chinense germplasm line with $M$. arenaria resistance conditioned by more than one dominant gene.

Our findings demonstrate that a single dominant gene conditions the high level of resistance to $M$. arenaria race 1 exhibited by the $C$. chinense germplasm lines PA-353 and PA-426. Results of allelism tests indicate that the resistance gene in each of these germplasm lines is allelic to a gene in $C$. апnиит 'Carolina Cayenne'. However, further research is needed to determine whether this dominant $M$. arenaria race 1 resistance gene in $C$. chinense is the $N$ gene that conditions the $M$. incognita resistance in $C$. аппиит. The availability of simply-inherited sources of resistance makes breeding for $M$. arenaria race 1 resistance a viable objective in $C$. chinense breeding programs. This objective should be readily obtained by the application of conventional plant breeding methodologies.

\section{Literature Cited}

Di Vito, M. and F. Saccardo. 1996. Resistance of pepper to root-knot nematodes (Meloidogyne spp.): Present and future, p. 55-56. In: D.N. Maynard (ed.). Proc. Natl. Pepper Conf., Naples, Fla., 8-11 Dec.

Di Vito, M., F. Saccardo, A. Errico, V. Zema, and G. Zaccheo. 1993. Genetics of resistance to root-knot nemateodes (Meloidogyne spp.) in
Capsicum chacoense, C. chinense and C. frutescens. J. Genet. Breeding 47:23-26.

Di Vito, M., F. Saccardo, N. La Gioia, A. Carella, G. Cecchini, and V. Papacchioli. 1985. Lines of Capsicum annuun resistant to root-knot nematodes obtained by interspecific hybridization $(C$. annuum $\times C$. frutescens). Genetica Agraria 39:322-323 (abstr.).

Fery, R.L. and P.D. Dukes. 1996. The inheritance of resistance to the southern root-knot nematode in 'Carolina Hot' cayenne pepper. J. Amer. Soc. Hort. Sci. 121:1024-1027.

Fery, R.L., P.D. Dukes, and W.L. Ogle. 1986. 'Carolina Cayenne' pepper. HortScience 21:330.

Fery, R.L., P.D. Dukes, and J.A. Thies. 1998. 'Carolina Wonder' and 'Charleston Belle': Southern root-knot nematode-resistant bell peppers. HortScience 33:900-902.

Fery, R.L. and J.A. Thies. 1997. Evaluation of Capsicum chinense Jacq. cultigens for resistance to the southern root-knot nematode. HortScience 32:923-926.

Fery, R.L. and J.A. Thies. 1998a. PA-353, PA-398, and PA-426: Southern root-knot nematode-resistant Capsicum chinense Jacq. germplasm lines. HortScience 33:760-761.

Fery, R.L. and J.A. Thies. 1998b. Genetic analysis of resistance to the southern root-knot nematode in Capsicum chinense Jacq. J. Amer. Soc. Hort. Sci. 123:1008-1011.

Hussey, R.S. and K.R. Barker. 1973. A comparison of methods of collecting inocula of Meloidogyne spp., including a new technique. Plant Dis. Rptr. 57:1025-1028.

Noe, J.P. 1992. Variability among populations of Meloidogyne arenaria. J. Nematol. 24:404-414.

Sasser, J.N. and C.C. Carter. 1982. Root-knot nematodes (Meloidogyne spp.): Identification, morphological and physiological variation, host range, ecology, and control, p. 21-32. In: R.D. Riggs (ed.). Nematology in the southern region of the United States. S. Coop. Ser. Bul. 276. Univ. Ark., Fayetteville.

Thies, J.A. and R.L. Fery. 2000. Characterization of resistance conferred by the $N$ gene to Meloidogyne arenaria races 1 and 2, M. hapla, and $M$. javanica in two sets of isogenic lines of Capsicum annuum L. J. Amer. Soc. Hort. Sci. 125:71-75.

Thies, J.A., J.D. Mueller, and R.L. Fery. 1997. Effectiveness of resistance to southern root-knot nematode in 'Carolina Cayenne' pepper in greenhouse, microplot, and field tests. J. Amer. Soc. Hort. Sci. 122:200-204. 